\title{
BIBLIO COUNSELING TO REDUCE THE EFFECTIVENESS OF STUDENT academic procrastination FORCE OF GUIDANCE AND COUNSELING
}

\author{
Erik Teguh Prakoso \\ erik@unikama.ac.id \\ University of Malang Kanjuruhan \\ Wida Reni Kristianti \\ wida8892@gmail.com \\ University of Malang Kanjuruhan
}

\begin{abstract}
Academic Procrastination is a manifestation form of avoidance in a task that should be done by an individual. Procrastinator deliberately to delay the work or tasks that should be solved. Thus procrastination is delay work on an employment or assignment that is done deliberately. This study uses a quantitative approach to design Quasi Experiment patterns pretest and posttest Group. The subjects in this study is the Student Guidance and Counseling Program 2015 University Kanjuruhan Malang forces amounting to 5 students. The research instrument uses a scale of academic procrastination. Data analysis technique used is statistically using SPSS 22:00 for windows. The results showed that based on the analysis of different test Wilcoxon between pretest and posttest generate value significant (two-tailed) $<0.05$ is 0.043 , which means the provision of treatment through counseling biblio effective to reduce the level of student academic procrastination. Based on the results of data presentation can be concluded that the study subjects experienced the difference after the treatment is done, so it can be said that the biblio effective counseling to reduce the level of academic procrastination.
\end{abstract}

Keywords: Academic Procrastination, Biblio counseling

\section{INTRODUCTION}

Procrastination is an activity avoid or delay important work to be done and have planned ahead without reasonable cause and is often done by students (Balkis and Duru, 2009). Procrastination is one manifestation of a person's work performance decline, and increased stress. Procrastination is basically caused by many factors, such as physical and psychological conditions of individuals, peers, parenting patterns, environmental conditions and so on.

Procrastination is not something new among students or teens. Procrastination or delay the work is often done by the students when students feel bored and unhappy with professors or certain subjects. This behavior, if continually done it will have a bad impact on the lives of these students do not pass one of them is in the eyes of certain courses or can not graduate studies at the college in accordance with the expectations of parents.

In fact, the behavior of delaying the work still going on in the school environment, not least in the university environment Kanjuruhan University of Malang. Behavior postpone academic work is done during the hours of certain subjects or home assignment given by the lecturer. Behavior postpone this work is due to several factors that cause students are reluctant to do the work of a 
lecturer in certain specified.

As a concrete example of the delay of work done by the students is to procrastinate given by the lecturer. One task of the course is usually the lecturer gives sufficient time limit for students to do the work. Although later the task will be stacked with the duties of lecturers and lecture others, if explored many reasons that lead to the students preferred to delay work on the assignment given, a common reason given student to put off tasks are as follows: 1) the level of student understanding will be the task less, 2) difficulty finding materials or materials on the task, 3) do not like the lecturer of the course, 4) students do not like the course that, 5) lazy to do the work for another friend would not be invited to cooperate in the task. The tasks that can actually be completed earlier than the deadline given by teachers, but students usually prefer to postpone work on the assignment to replace the jobs are less important as watching movies, playing games, dating, hanging out with friends (coffee), recreation or a picnic and so for self-satisfaction, eventually the task will continue to accumulate and continue to be covered by other tasks so that students will hassles in completing tasks or even tasks are not performed at all and the impact on the student's academic value.

Related to this explanation the counselor should have to provide services in the form of alleviating the problem to reduce the level of academic procrastination done by the students. One approach at this time that began to be studied is the bibliocounseling, the approach using print media. According Nursalim (2013: 13) printed materials media is making visual media through the printing process(printing/offset).The media present a message through letters and pictures that illustrated to further clarify the message or information presented. One type of media printed materials are textbooks.

The technique uses textbooks as the treatment is defined as Bibliotheraphy. Bibliocounseling is another name and was adapted from the biblio therapy has been practiced to change human behavior (Brammer and Shostrom, 1982). Biblio guidance counseling is a technique that is done by using a book or a story in which there are teachings about caring behavior. The book is the media to gain insight, knowledge, information and entertainment. In addition, the book can serve as therapy or cure for people with mental disorders (anxiety disorders, trauma and stress). Utilization of the book as a medium of therapy is called bibliotherapy Jachna (2005: 1).

Against back problems, needs to be done research to find Biblio effectiveness of counseling for Procrastination lower levels of student academic counseling and guidance forces 2015 .

\section{RESEARCH METHODS}

This study is study, Quasi Experiment using the pattern of pre-test and post-test Group.In this study, researchers treated to reduce the level of student procrastination by using books or reading material, which had previously been known to target the initial conditions before being treated using a pre-test and post-test after being treated. To determine the extent to which the effectiveness of the use of books or reading material to decrease the level of student academic procrastination.

In this study taking subjects using technique purposive sampling in which a subject to be researched already known in advance by using interviews, observations, information from lecturers subject specific and use a pre-test, and after it are the subject of 
research is 5 student BK class of 2015 highlevel academic procrastination.

Instruments in this study using 1) Books biblio counseling contents stories related to academic procrastination 2) data collection instruments using academic procrastination scale, sheet reflection and selfevaluation sheet.

In use biblio counseling by Oslen (in Suparyo 2010: 25) there are five stages, namely: 1) First, start with motivation. Researcher or counselor can provide preliminary activities, such as games or play a role, which can motivate the counselee to be actively involved inactivities. treatment 2) Second, to allow enough time to read the reading materials that have been prepared to complete. Previously, researchers/ counselors have understood correctly reading materials provided. 3) Third, Do incubation. Researcher/ counselors provide time in counselees to meditate and reflect on the material they have just read. 4) Fourth, the follow-up. We recommend a follow-up carried out by the method of discussion. Through discussion counselee get a space to exchange views giving rise to new ideas. Then, the researchers I counselors help counselees to realize that knowledge in his life. 5) Fifth, the evaluation. Evaluation should be carried out independently by the counselee. This is done to provoke counselee the conclusion that due diligence and understand the meaning of the experiences.

Real experiences that will be taught to students through reading these stories aim to help counselors be more proactive and enabling students in understand and be able to resolve the problem experienced.

Biblio guidance counseling itself is a technique that uses a book or a story in which there are teachings about caring behavior.
Where the book itself is a medium or a means to gain insight, knowledge, information and entertainment. In addition the book is also one media treatment or cure mental (anxiety disorders, trauma and stress).

\section{RESULTS AND DISCUSSION}

From the results of experiments conducted results pretest and posttest conducted on the subject of experiments / studies show that counseling biblio short stories (short stories) can be influential in reducing the level of student academic procrastination guidance and counseling force 2015.

Based on test wilcoxon calculations, data the difference between the level of academic procrastination before being given treatment (pretest)and after administration of treatment (posttest)using biblio counseling regularly and and use the evaluation as a follow up of the provision of treatment. The following is a comparison table of the prior administration of treatment (pretest) and after the administration of treatment (posttest)do.

Table 1. Comparison of scores pretest and post test

\begin{tabular}{lclrll}
\hline $\begin{array}{l}\text { Cate- } \\
\text { gory }\end{array}$ & $\begin{array}{l}\text { Post } \\
\text { test }\end{array}$ & $\begin{array}{l}\text { Cate- } \\
\text { gories }\end{array}$ & $\begin{array}{l}\text { Pre- } \\
\text { test }\end{array}$ & $\begin{array}{l}\text { Subject } \\
\text { Research }\end{array}$ & No. \\
\hline Low & 122 & $\begin{array}{l}\text { Very } \\
\text { High }\end{array}$ & 86 & AP & 1 \\
Low & 129 & $\begin{array}{l}\text { Very } \\
\text { high }\end{array}$ & 74 & KR & 2. \\
& & & AK & 3. \\
Low & 132 & High & 90 & H. \\
Low & 125 & High & 94 & RS & 4. \\
low & 136 & high & 92 & UL & 5. \\
\hline 436 & & 644 & & Total & \\
\hline
\end{tabular}

Based on table 1. It is known that 5 subjects of the experiment / study has a low score, which means the fifth research subjects have a high level of academic procrastination before being given treatment. Meanwhile, after being given treatment scores obtained five research subjects turned into high which 
means that the fifth research subjects had lower levels of procrastination. Following the presentation of the data graph comparison results pretest and posttestscores.

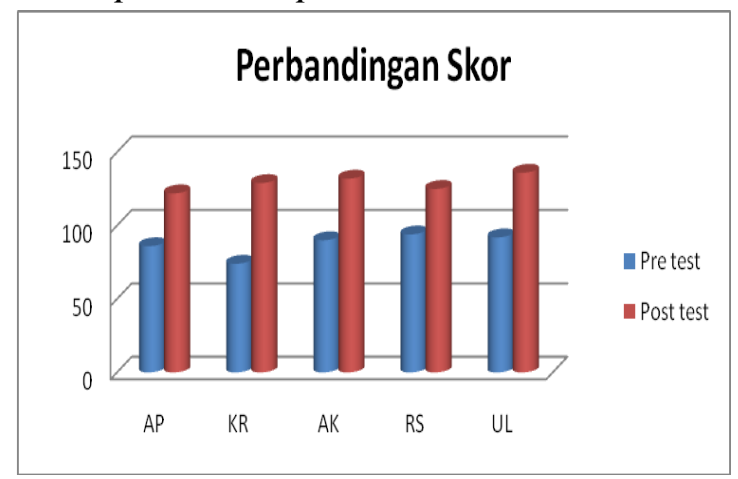

Figure 1. Graph comparison score pretest and posttest

Data from presentation graphics can be read that the level of academic procrastination behavior, before being given a treatment high(not reduce the level of academic Procrastination) and after the administration of treatment to reduce the level of academic procrastination can be decreased (have started to reduce academic procrastination behavior). The graph shows the percentage decrease in the level of academic procrastination experienced by research subjects, subjects AP showed a decline of $25.71 \%$, subject KR showed a decline of $39.28 \%$, AK subjects showed a decrease of $30 \%$, subject RS showed a decline of $22.14 \%$, and UL subjects showed a decline of $31.42 \%$. Based on the statement can be interpreted that academic procrastination behavior decreases because each student has been willing to reduce academic procrastination behavior after the treatment is done. So it can be concluded that the biblio counseling is effective to reduce the level of student academic procrastination guidance and counseling force, 2015.

The conclusion of the data is supported by the Wilcoxon test. The results of testing the hypothesis by using Wilcoxon test showed the results of the analysis as follows:

Table 2 Test Results Wilcoxon

Test Statistics $^{\mathrm{a}}$

\begin{tabular}{|r|l|}
\hline post - before & \\
\hline $\begin{array}{r}-2.023^{\mathrm{b}} \\
\text { (2-tailed),043 }\end{array}$ & Z Asymp. Sig. \\
\hline
\end{tabular}

b. Based on negative ranks.

Table 2 shows the decline in academic procrastination level of support in the process of data analysis using analysis SPSS 22:00 for windows is by using the Wilcoxon test known that sig (2-tailed) $0.043<0.05$ then the results of the Wilcoxon test showed that the probability <0, 05 means that there are differences in the level of academic procrastination before and after the treatment is done.

Biblio effective counseling to reduce the level of student academic procrastination in force BK, 2015. The level of academic procrastination in students has decreased compared to before is treatment given. According Sharck and Engels (in Lasan: 1997) biblio counseling is tutoring that helps individuals independently to understand themselves and the environment, to learn from the environment and finding solutions to problems. Biblio counseling can be defined as an activity to intervene in individual thought by using a reading, so after reading the passage individuals can acquire new information and can apply it in everyday life.

Given reading material serves to divert the orientation and provide positive views that arouse awareness. In this study, the research subjects are given short stories and articles which contain about academic procrastination is bad for the development of the human brain. 
Short stories and articles that provide insights and new situations that can make the reader think critically. The research subjects read and understand what is in the book, then reflect. Through the help of the discussion questions progressively generate creative insights. Thus, much information can be obtained and will know the bad effects of academic procrastination for research subjects. The research subjects have a better understanding. They also committed not to academic procrastination back.

\section{CONCLUSION}

Based on research conducted at the University of Malang exactly Kanjuruhan Guidance and Counseling Program and the results of the analysis in chapter IV, it can be concluded that the biblio counseling can be used to lower the rank of procrastination in students 2015 BK force effectively. It can be summarized as follows: 1) The level of student academic procrastination before and after treatment using the technique of biblio counseling undergone significant changes, which showed a decline. 2) Mechanical biblio effective counseling to reduce academic procrastination behavior, can also be seen in the process. First, prepare the reading lists of Procrastination. Preparation of reading is very important in determining the success of biblio counseling. Reading tailored to students who were given treatment. Based on the results of research already shows that the techniques described in the biblio effective counseling to reduce students' academic procrastination behavior

\section{BIBLIOGRAPHY}

Anima. Indonesia Pshichological journal. 2014. The Effect of Group bibliotherapy in Reducing Social
Anxiety of Gifted and Talented Adolescents Volume 29. No.04

Arikunto, Suharsimi, 2010. Research Procedure; A Practical Approach. Jakarta: PT. Rineka Reserved.

Azwar, Saifuddin.2010. Reliability and Validity of 3rd Edition Prints X.Yogyakarta: Student Library.

Burka, JB, \& Yuen, LM 1983. Procrastination: Why you do it, what to do about it, Reading,MA: AddisonWesley

Corey, Gerald. (2012). Theory and Counselling Psychotherapy. Jakarta: PT Refika Aditama

Ghufron, M. Nur.2003.Relationship SelfControl and Perception of Youth towards Implementation of Parental Discipline with Academic Procrastination. Skripsi. Yogyakarta: University of Gajah Mada.

Ghufron. MN \& Risnawati, R. 2012. Theories of Psychology. Jogjakarta: Ar-Ruzz Media

Journal Student Science University of Surabaya. 2013. Relationship Between Procrastination Academic and Student Academic Achievement Psikologi- Ubaya Faculty Volume 02. No.01.

Student Science Journal Universitas Surabaya. 2013. Relationship Between Depression and Academic Procrastination. Volume 02. No.02.

Journal of Nursing. 2014. bibliotherapy Lowers Anxiety Levels of School Age Children Who Undergo Hospitalization In Jakarta Islamic Hospital.Volume 1. No. 02.

Journal of Social Humanities Makara Seri Unversirtas Surabaya. 2013. Procrastination Academic and SelfControl in Student Thesis Faculty of 
Psychology, of University Surabaya Volume VI. No. 02

Journal of Psychology. 2014. Methods of bibliotherapy and Discussion Moral Dilemmaon Character Development Responsibility.Volume 41. No. 01

Herlina. (2013). Bibliotherapy Troubleshooting Children and Youth Through Books. Bandung: Pustaka Cendikia. Utama

Knaus, W. 2010. End Procrastination Now! Get it Dont With a Proven Psychological Approach. New York: McGraw-Hill

Knaus, W. 2010. The Procrastination Workbook. Your Personalized Program for Breaking Free from Patterns that Hold You Back. New Harbinger. Publ. Inc.

Lasan, Blasius. 1997. Influence Bibliocounseling As Engineering Group Counseling To Reduce Social Prejudice Student Ethnicity and Ethnic Tioghoa Java. Thesis. Malang: $\mathrm{UM}$

Nugrasanti. (2006). Locus of Control and Procrastination Students. Journal, Provitae 2 (1),25-33.
Salomon, LJ \& Rothbulum, ED 2001. Academic procrastination: Frequency and Cognitive-Behavioral Correlates. Journal of Counseling Psychology, 31, 504-510.

Shectman. Zipporah. (2009). Treating Child and Adolescent Aggression Through bibliotherapy. New York: Springer Science and Business Media.

Sugiyono. 2010. Research Quantitative Methods,Qualitative and R \& D. Bandung: Alfabeta.

Suparyo, Yossy.2010.Bibliotehraphy. Source: http://www//countryside. wordpress.com.accessed on 12 april 2016pkl 20:00

Kanjuruhan University of Malang. 2013. Guidelines for Writing Skripsi. Issue 3

Revelation, Ira. 2016. The effectiveness of counseling Biblio To Habits Reduce Hard Drinks At Xii grade students of SMK PGRI 1 Blitar. Skripsi. Malang: Universitas Kanjuruhan 